\title{
THE NONPROTEIN CONSTITUENTS OF EDEMA FLUIDS *
}

\author{
W. DENIS, Рн.D.
}

WITH THE ASSISTANCE, OF

\author{
A. S. MINOT, A.B. \\ BOSTON
}

Although many investigations have been published regarding the proteins of edema fluids, the available data regarding their nonprotein constituents are exceedingly meager. In the standard and frequently copied analyses to be found in most textbooks these bodies are almost universally grouped together under the vague title of "extractives," and are to be found recorded under this general heading, together with the more elaborate analyses of the protein and inorganic constituents. By means of the micromethods which have come into general use during the past five years we now know, in a general way at least, the level at which the more common nonnitrogenous bodies are maintained in the blood in health and in disease. Investigations by modern methods along this line have, however, been extended in only a few instances ${ }^{1}$ to body fluids other than blood.

In view of this lack of available data it has seemed worth while to publish the results obtained by the analysis of a small number of edema fluids in which we have made determinations of most of the ordinary nonprotein bodies occurring in such material.

In Table 1 are presented the results obtained on a series of fluids (pleuritic, ascitic and hydrocele) which were selected from the available material because they illustrate the chemical variations ordinarily to be met with in unselected clinical material.

The methods of analysis used were as follows:

Total Solids.-Ten c.c. of the fluid was dried to constant weight in a platinum dish placed in an air bath kept at a temperature of 100 c.c.

Total Protein.-By calculations from the total nitrogen, which was determined by the Kjeldahl-Gunning method.

Nomprotein Nitrogen and Urea.-By the direct nesslerization methods of Folin and Denis." Fine. $^{3}$

Uric Acid.-By the method of Folin and Denis as modified by Myers and

* Submitted for publication July 3, 1917.

* From the Chemical Laboratory of the Massachusetts General Hospital.

1. Fine, M. S., and Myers, V. C.: Proc. Soc. for Exper. Biol. and Med., 1916, 13, 126. Kahn and Neal: ibid., 1916, 14, 26.

2. Folin, O., and Denis, W.: Jour. Biol. Chem., 1916, 26, 473

3. Myers, V. C., and Fine, M. S.: The Significance of the Uric Acid, Urea and Creatinin of the Blood in Nephritis, The Archives Int. Med., 1916, 17, 570. 
TABLE 1.-Results of Analysis of Edema-

\begin{tabular}{|c|c|c|c|c|c|}
\hline \multirow[b]{2}{*}{ No. } & \multirow[b]{2}{*}{ Description } & & \multirow{2}{*}{$\begin{array}{l}\text { Specific } \\
\text { Gravity }\end{array}$} & \multicolumn{2}{|c|}{ Mg. per 100 O.c. Fluid } \\
\hline & & & & $\begin{array}{c}\text { Total } \\
\text { Protein }\end{array}$ & $\begin{array}{l}\text { Nonprotein } \\
\text { Nitrogen }\end{array}$ \\
\hline 2 & Chest fluid; eardiac....................... & $\ldots \ldots \ldots \ldots \ldots$ & 1.016 & 1,950 & 25 \\
\hline 12 & Pleuritic fluid; pleurisy................ & & 1.032 & 3,981 & 36 \\
\hline 3 & Ascitic fluid; tuberculous peritonitis.... & & 1.040 & 3,375 & 38 \\
\hline 9 & Ascitic fluid; cirrhosis of liver.......... & & 1.012 & 712 & 33 \\
\hline 6 & Ascitic fiuld; cirrhosis of liver........ & & 1.008 & 916 & 28 \\
\hline 17 & Ascitis fluid; cirrhosis of liver.......... & & 1.015 & 1,906 & 37 \\
\hline 18 & Same patient as No. 17,5 days later.. & & 1.013 & $1, \mathbf{4 1 2}$ & $\$ 1$ \\
\hline 27 & Ascitic fluid; portal obstruetion....... & & 1.017 & 1,956 & 25 \\
\hline 28 & Same patient as No. 27,6 days Jater.... & & 1.015 & 1,750 & 17 \\
\hline $31 \mathrm{H}$ & Hydroceie fluid $\ldots \ldots \ldots \ldots \ldots \ldots \ldots \ldots \ldots$ & $\cdot$ & 1.029 & $\ldots$. & .. \\
\hline $32 \mathbf{H}$ & Same patient as $31 \mathrm{H}, 24$ hours later.. & $\cdots$ & 1.030 & 4,250 & .. \\
\hline $42 \mathrm{H}$ & Hydrocele fluid $. . . \ldots \ldots \ldots .$. & $\ldots \ldots \ldots, \ldots, \cdots$ & 1.022 & 3,637 & 43 \\
\hline 47H & Hydrocele fluld ...... & & 1.019 & 3,681 & 39 \\
\hline $24 \mathrm{H}$ & Hydrocele fiuid & & 1.025 & 6.431 & 30 \\
\hline 14H & Hydrocele fluid .... & & $\ldots$. & 287 & 3 \\
\hline
\end{tabular}

TABLE 2.-Results of ANalysis of Ascttic Fluid-

\begin{tabular}{|c|c|c|c|c|c|c|c|}
\hline \multirow[b]{2}{*}{ Date } & \multirow[b]{2}{*}{ Volume, C.c. } & \multirow[b]{2}{*}{ Sp. Gr. } & \multirow[b]{2}{*}{$\begin{array}{l}\text { Total } \\
\text { Protein }\end{array}$} & \multicolumn{4}{|c|}{ Mg. per 100 O.c. Fluld } \\
\hline & & & & $\begin{array}{l}\text { Nonprotein } \\
\text { Nitrogen }\end{array}$ & $\begin{array}{c}\text { Urea } \\
\text { Nitrogen }\end{array}$ & Orie Acid & Creatinin \\
\hline $11 / 15$ & 8.000 & 1.014 & 1,781 & 26 & 14 & $\cdots$ & 0.5 \\
\hline $11 / 17$ & 5,000 & 1.016 & 2.156 & 38 & 19 & $\ldots$ & 0.7 \\
\hline $11 / 27$ & 10,000 & 1.012 & 1,269 & 27 & 10 & 1.8 & $\cdots$ \\
\hline $12 / 5$ & 5,000 & 1.012 & 1,231 & 29 & 10 & 4.6 & 0.5 \\
\hline $12 / 11$ & 3,500 & 1.012 & 1,250 & 29 & 13 & 3.2 & 0.8 \\
\hline $12 / 18$ & 3.700 & 1.011 & $\mathbf{1 , 1 2 5}$ & 29 & 8 & 1.6 & 0.8 \\
\hline $12 / 26$ & 3,280 & 1.011 & 1,119 & 11 & 7 & 1.5 & $\cdots$ \\
\hline $1 / 2$ & 3,620 & 1.011 & 962 & 28 & 10 & 1.8 & $\cdots$ \\
\hline $1 / 10$ & 3,280 & 1.011 & 1,119 & 17 & 9 & 1.8 & ... \\
\hline $1 / 19$ & 3,300 & 1.011 & 1,400 & 23 & 10 & $\cdots$ & $\ldots$ \\
\hline $2 / 1$ & 2,500 & 2.012 & 1,400 & 26 & 12 & 2.1 & $\cdots$ \\
\hline $2 / 6$ & 1.970 & T.013 & 1,584 & 27 & 12 & $\cdots$ & $\cdots$ \\
\hline
\end{tabular}


-Fluids for Nonprotein Bodies

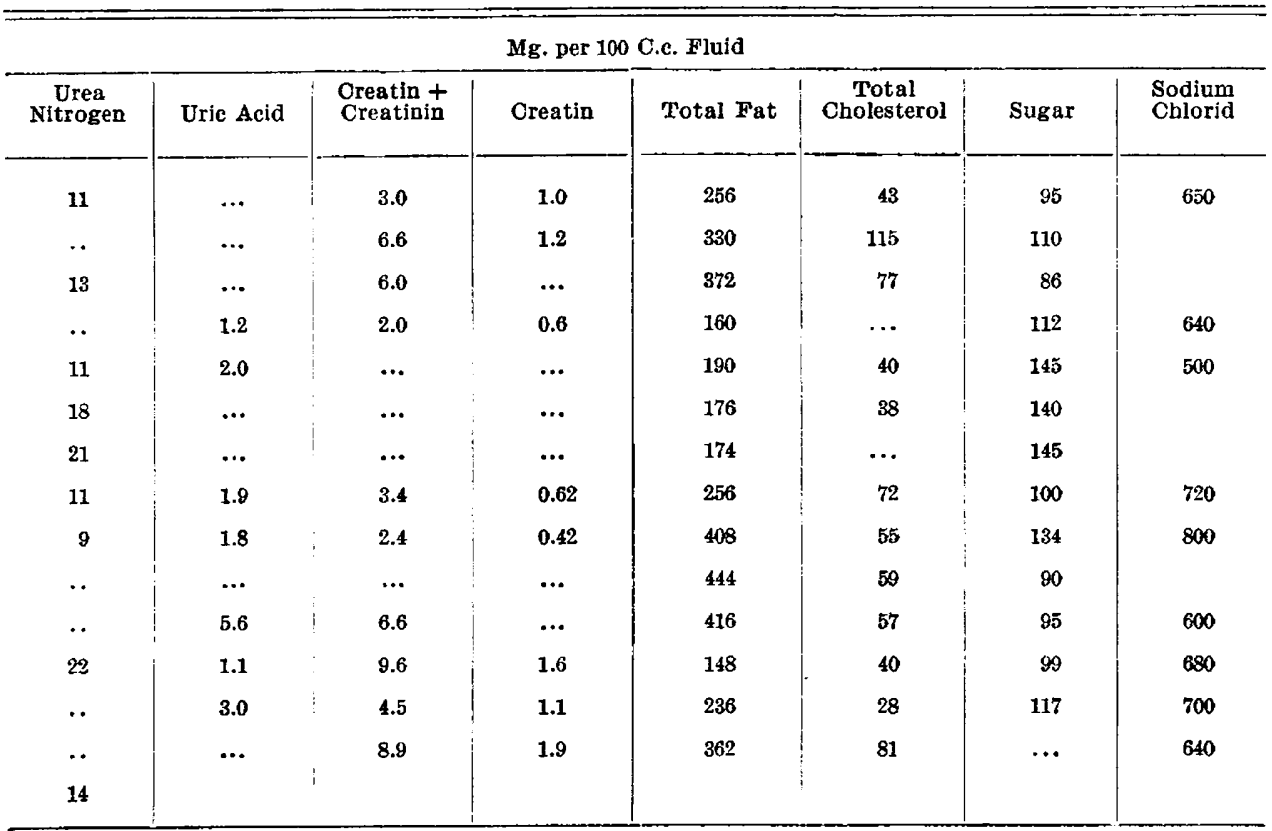

-From a Patient with Cirrhosis of the Liver

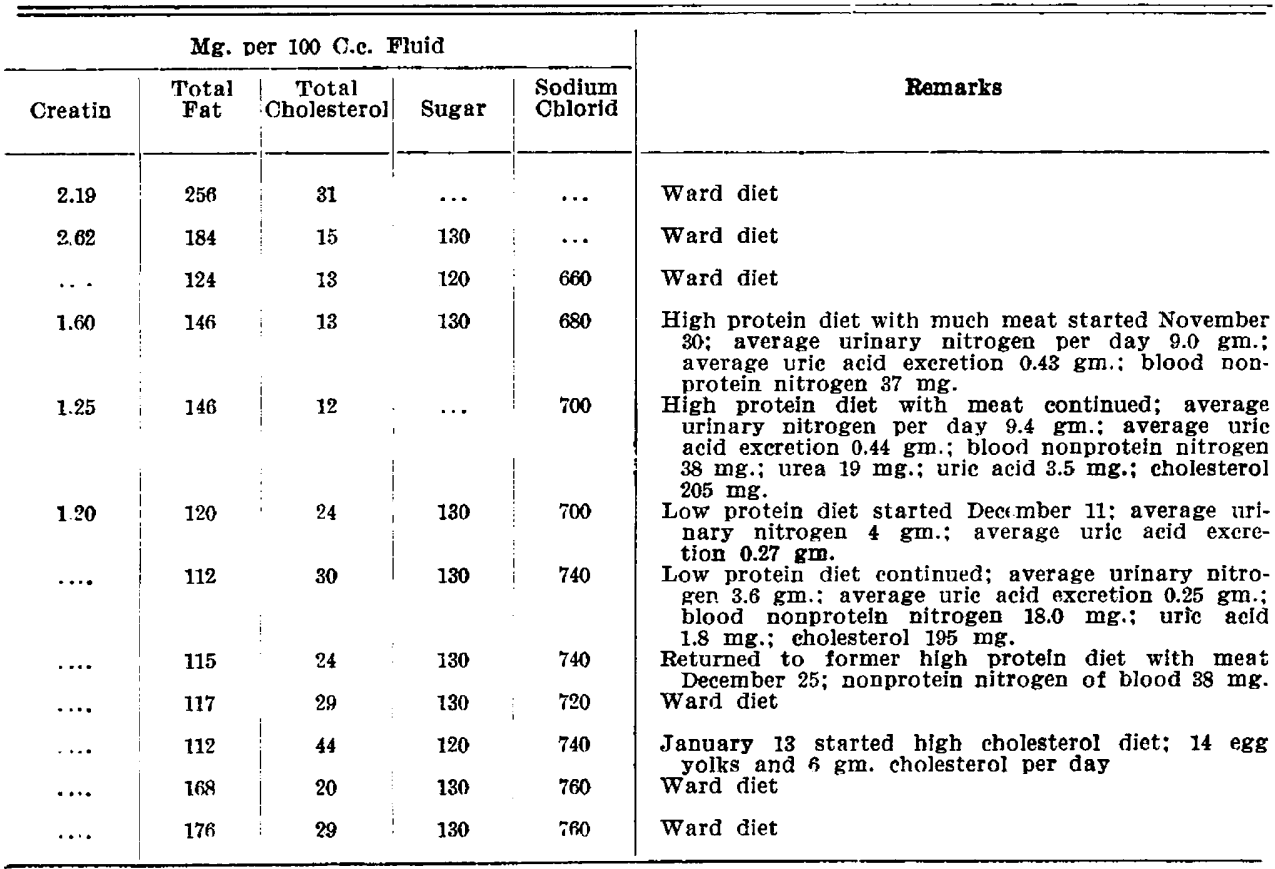

Downloaded From: http://archinte.jamanetwork.com/ by a University of Iowa User on 06/14/2015 
Creatin and Creatinin.-By Folin's methods."

Total Fat and Cholesterol.-By Bloor's $\mathrm{s}^{5}$ micromethods.

Sugar.-By the method of Lewis and Benedict, ${ }^{\circ}$ as modified by Myers and Bailey.

Sodium Chlorid.-By the Volhard method, after precipitating the proteins by means of magnesium sulphate and acetic acid.

It was not possible to obtain blood from the patients the results of whose fluids are given in Table 1. Below are presented the data obtained on a few cases of ascites, pleurisy and hydrothorax in which bloods taken at the time of parasynthesis were examined by the same method used in the analysis of the fluid.

Ascitic Fluid 1.-Man, aged 60 years. Peritonitis (tubercular). Volume of fluid obtained, 3,800 c.c.; a clear, straw colored liquid, specific gravity 1.020 .

\begin{tabular}{|c|c|c|}
\hline & $\sim \mathrm{Mg}$. Per 100 & C.c. -7 \\
\hline Determination & Fluid & Blood \\
\hline Total solids... & $6,740.0$ & \\
\hline Total protein.............. & $4,919.0$ & \\
\hline Nonprotein nitrogen......... & 31.0 & 30.0 \\
\hline Urea nitrogen.. & 15.0 & 12.0 \\
\hline Uric acid $\ldots \ldots \ldots \ldots \ldots \ldots$ & 2.8 & \\
\hline Creatinin & 0.7 & \\
\hline Creatin + creatinin.......... & 4.8 & 7.7 \\
\hline Sugar $\ldots \ldots \ldots, \ldots \ldots \ldots \ldots$ & 141.0 & 140.0 \\
\hline Total fatty acids............ & 408.0 & 560.0 \\
\hline Total cholesterol $\ldots \ldots \ldots \ldots \ldots$ & 89.0 & 208.0 \\
\hline Sodium chlorid............. & 720.0 & \\
\hline
\end{tabular}

Ascitic Fluid 2.-Man, aged 56 years. Cirrhosis of the liver; alcoholism. Last tap eleven days previously; volume of fluid obtained, 6,300 c.c. Specific gravity 1.012 .

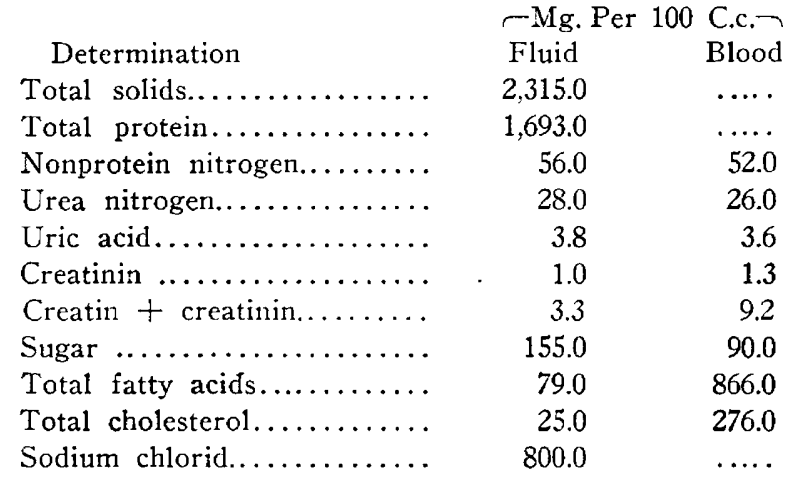

4. Folin, O.: Jour. Biol. Chem., 1914, 17, 475.

5. Bloor, W. R.: Jour. Biol. Chem., 1914, 17, 377; 1916, 24, 227.

6. Lewis, R. C., and Benedict, S. R.: Jour. Biol. Chem., 1915, 20, 61.

7. Myers, V. C., and Bailey, C. V.: Jour. Biol. Chem., 1916, 24, 147. 
Ascitic Fluid 3.-Woman, aged 45 years. Cirrhosis of the liver; syphilis; last tap nine days previously; volume of fluid obtained, 5,400 c.c.; specific gravity 1.012 .

\begin{tabular}{|c|c|c|}
\hline & \multicolumn{2}{|c|}{-Mg. Per 100 C.c. $\neg$} \\
\hline Determination & Fluid & Blood \\
\hline Total solids..... & $2,234.0$ & . \\
\hline Total protein............... & $1,400.0$ & \\
\hline Nonprotein nitrogen......... & 25.0 & 26.0 \\
\hline Urea nitrogen............... & 12.0 & 12.0 \\
\hline Uric acid $\ldots \ldots \ldots \ldots \ldots \ldots \ldots$ & 2.0 & 2.0 \\
\hline Creatinin $\ldots \ldots \ldots \ldots \ldots, \ldots$ & 0.8 & 1.3 \\
\hline Creatin + creatinin.......... & 3.1 & 7.3 \\
\hline Sugar $\ldots \ldots \ldots \ldots \ldots \ldots \ldots \ldots$ & 100.0 & 93.0 \\
\hline Total fatty acids $\ldots \ldots \ldots \ldots \ldots$ & 90.0 & \\
\hline Total cholesterol............ & 22.0 & \\
\hline Sodium chlorid... & 600.0 & \\
\hline
\end{tabular}

Ascitic Fluid 4.-Woman, aged 66 years. Diagnosis, probably portal obstruction; last tap eleven days previously; volume of fluid obtained, 5,500 c.c.; specific gravity 1.011 .

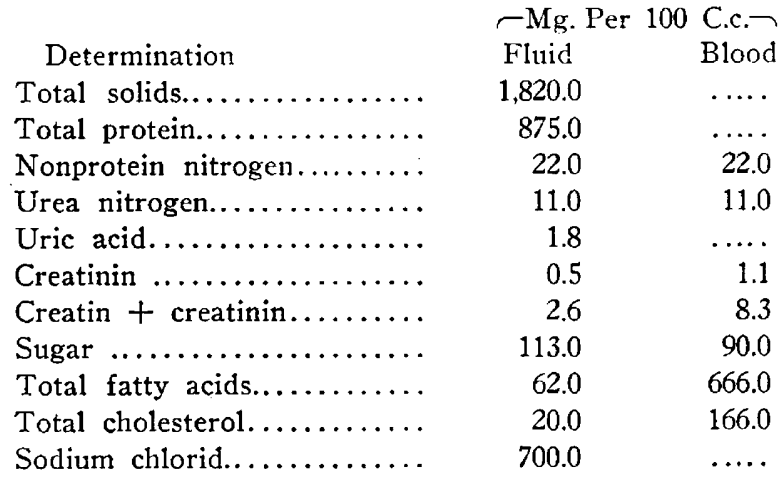

Chest Fluid 1.-Man, aged 19 years. Acute pleurisy; first tap; volume of fluid obtained, 1,260 c.c. A clear straw colored fluid of specific gravity 1.026, which clotted rapidly.

\begin{tabular}{|c|c|c|}
\hline & -Mg. Per 100 & C.c. $\neg$ \\
\hline Determination & Fluid & Blood \\
\hline Total solids..... & 6.585 .0 & \\
\hline Total protein.............. & $5,543.0$ & \\
\hline Nonprotein nitrogen......... & 36.0 & 28.0 \\
\hline Urea nitrogen................. & 16.0 & 14.0 \\
\hline Uric acid................ & 3.3 & 3.0 \\
\hline Creatinin $\ldots \ldots \ldots \ldots \ldots \ldots \ldots$ & 0.5 & \\
\hline Creatin and creatinin........ & 5.3 & 7.8 \\
\hline Sugar $\ldots \ldots, \ldots \ldots \ldots \ldots \ldots, \ldots$ & 101.0 & 103.0 \\
\hline Total fatty acids............ & 328.0 & 810.0 \\
\hline Total cholesterol............. & 84.0 & 140.0 \\
\hline
\end{tabular}


Chest Fluid 2.-Man, aged 25 years. Tuberculosis; pleurisy; volume of fluid obtained, 1,500 c.c. A deep yellow liquid, specific gravity 1.022, from which fibrin began to separate soon after removal from the body; total cells, 800 per c.mm.

\begin{tabular}{|c|c|c|}
\hline & \multicolumn{2}{|c|}{ †Mg. Per 100 C.c. $\neg$} \\
\hline Determination & Fluid & Blood \\
\hline Total solids... & $5,952.0$ & \\
\hline Total protein... & $4,548.0$ & \\
\hline Nonprotein nitrogen.......... & 22.0 & 25.0 \\
\hline Urea nitrogen.............. & 11.0 & 12.0 \\
\hline Uric acid....... & 2.5 & 2.0 \\
\hline Creatinin $\ldots \ldots \ldots \ldots \ldots \ldots \ldots$ & 0.8 & \\
\hline Creatin and creatinin......... & 6.8 & 8.9 \\
\hline Sugar $\ldots \ldots, \ldots, \ldots, \ldots, \cdots$ & 95.0 & 90.0 \\
\hline Total fatty acids............ & 650.0 & 910.0 \\
\hline Total cholesterol.............. & 108.0 & 250.0 \\
\hline Sodium chlorid............. & 680.0 & \\
\hline
\end{tabular}

Chest Fluid 3.-Man, aged 39 years. Diagnosis, "probably malignant growth;" third tap in ten days; a dark brown fluid, red cells, 1,000.000 per c.mm.; specific gravity 1.016 .

\begin{tabular}{|c|c|c|}
\hline & $\sim \mathrm{Mg}$. Per & 100 C.c. $\neg$ \\
\hline Determination & Fluid & Blood \\
\hline Total solids.............. & $5,225.0$ & $\cdots$ \\
\hline Total protein................ & $3,587.0$ & \\
\hline Nonprotein nitrogen.......... & 27.0 & 28.0 \\
\hline Urea nitrogen............... & 13.5 & 14.0 \\
\hline Uric acid................ & 3.0 & 2.8 \\
\hline Creatinin $\ldots \ldots \ldots \ldots \ldots \ldots$ & 0.8 & 1.0 \\
\hline Creatin and creatinin........ & 3.5 & 7.4 \\
\hline Sugar $\ldots \ldots \ldots \ldots \ldots$ & 110.0 & 111.0 \\
\hline Total fatty acids.... & 240.0 & $1,000.0$ \\
\hline Total cholesterol...... & 86.0 & 333.0 \\
\hline Sodium chlorid............. & 680.0 & \\
\hline
\end{tabular}

Chcst Fluid 4.-Man, aged 42 years. Cardiac, general edema; volume of fluid obtained, 1,350 c.c.; a slightly cloudy, pale yellow fluid, of specific gravity 1.018 .

\begin{tabular}{|c|c|c|}
\hline & $-\mathrm{Mg}$ & C.c. $\neg$ \\
\hline Determination & Fluid & Blood \\
\hline Total solids............... & $4,400.0$ & …. \\
\hline Total protein................ & $3,324.0$ & \\
\hline Nonprotein nitrogen......... & 23.0 & 26.0 \\
\hline Urea nitrogen $\ldots \ldots \ldots \ldots \ldots \ldots$ & 11.0 & 13.0 \\
\hline Uric acid $, \ldots \ldots, \ldots, \ldots, \ldots$, & 2.4 & 2.6 \\
\hline Creatinin $\ldots \ldots \ldots \ldots \ldots \ldots \ldots$ & 1.1 & \\
\hline Creatin and creatinin.......... & 4.6 & 8.0 \\
\hline Sugar $\ldots \ldots \ldots \ldots, \ldots, \ldots$ & 117.0 & \\
\hline Total fatty acids........... & 226.0 & \\
\hline Total cholesterol........... & 89.0 & \\
\hline Sodium chlorid............ & 700.0 & \\
\hline
\end{tabular}


Chest Fluid 5.-Woman, aged 47 years. Mitral stenosis and regurgitation; anasarca; first tap; volume of fluid obtained, 1,400 c.c.; a pale yellow, clear fluid, of specific gravity 1.010 .

\begin{tabular}{|c|c|c|}
\hline & -Mg. Per 100 & C.c. \\
\hline Determination & Fluid & Blood \\
\hline Total solids..... & $1,832.0$ & \\
\hline Total protein.... & 763.0 & \\
\hline Nonprotein nitrogen.......... & 32.0 & 34.0 \\
\hline Urea nitrogen.............. & 16.0 & 17.0 \\
\hline Uric acid. $, \ldots \ldots, \ldots, \ldots, \ldots$ & 2.0 & \\
\hline Creatinin $\ldots \ldots \ldots \ldots \ldots \ldots$ & 0.6 & \\
\hline Creatin and creatinin......... & 2.6 & \\
\hline Sugar $\ldots \ldots, \ldots \ldots \ldots, \ldots, \ldots$ & 109.0 & \\
\hline Total fatty acids........... & 90.0 & 824.0 \\
\hline Total cholesterol............ & 39.0 & 240.0 \\
\hline Sodium chlorid............ & 600.0 & \\
\hline
\end{tabular}

The results here presented indicate that the concentration of most of the nonprotein nitrogenous constituents belonging to the class of crystalloids, namely, urea, uric acid and creatinin, occur in edema fluids in about the same concentration as in the blood, a fact already pointed out for urea by Javal and Adler. ${ }^{8}$ While the sugar content of the pleuritic fluids is about that of normal blood, it is to be noted that in the case of the ascitic fluids, particularly those obtained from patients suffering from cirrhosis of the liver, it is notably high.

The figures obtained for total creatinin (creatin + preformed creatinin) are, on the other hand, lower than those obtained on whole blood. Wilson and Plass ${ }^{2}$ have recently published a criticism of the Folin method for the determination of creatin in blood, the method by means of which these determinations were made, in which it is said that this procedure may, on hemolyzed blood, give figures 100 per cent. greater than those obtained by the acetic acid method used by these authors, a method which in their opinion is theoretically less open to disturbing factors than is the method of picric acid precipitation. In plasma and in unhemolyzed blood they obtained fairly concordant results in parallel determinations made by the two methods. The same investigators have also pointed out the interesting fact that creatin occurs largely in the corpuscles; little, and, in some cases, none at all, have been found by them in human plasma.

The results presented here were obtained before the publication of the paper of Wilson and Plass, and it has therefore not been possible to make parallel determinations by their method on these fluids; as, however, the creatin and creatinin determinations reported were made

8. Javal and Adler: Compt. rend Soc. de biol., 1906, 61, 235. Wells and Hedenburg: Jour. Infect. Dis., 1912, 2, 349.

9. Wilson and Plass: Jour. Biol. Chem., 1917, 29, 413. 
on unhemolyzed blood, and as the edema fluids examined contained, with one exception, no red cells, it is safe to conclude that the disturbing factors pointed out by Wilson and Plass were probably not operative in connection with the results presented here.

Considering the small number of cells occurring in edema fluids, the figures for creatin found in the case of these exudates and transudates is, in view of the findings of Wilson and Plass, surprising. It should be noted that while the creatin content of the fluids obtained from chronic cases is exceedingly low (compared to the level at which this product occurs in the blood), those obtained from the more acute cases present, as a rule, much higher values (Chest Fluid 2), a fact which may perhaps, in part, be accounted for by the higher cell content of fluids of the more acute type; although in considering this theory the possible influence of autolytic action should not be ignored.

The results obtained on the lipoid constituents determined (total fat and cholesterol) are somewhat similar to those obtained with creatin. In fluids of the purely transudate type the amounts of fat and cholesterol are small (Ascitic Fluids 3 and 4, Chest Fluid 5), while in exudates (Ascitic Fluid 7, Chest Fluid 1) the quantities of fat and of cholesterol present are much increased. Here again the relative number of cells present in the two types of fluids may be suggested as the cause of the difference in composition, for, as is well known, white cells are relatively rich both in neutral fat and in cholesterol.

The relatively small proportion of cholesterol to total fatty acids, if we take as a standard the analyses of "fasting" human blood published by Bloor, ${ }^{10}$ is also striking. ${ }^{11}$

It is now recognized that the concentration of many of the nonprotein constituents of the blood of normal persons may be influenced by diet; in cases of nephritis the effect is even more marked. Experimental data regarding the effect of diet on the nonprotein constituents of body fluids other than blood are, however, lacking. We have recently had the opportunity of making a series of observations on ascitic fluids obtained from a case of liver cirrhosis in which the patient was tapped at intervals of six or eight days, and have thus been able to observe the influence of changes in food intake on the composition of the transudate.

The subject of these experiments was an Italian, aged 51 years, weighing 138 pounds. The diagnosis was cirrhosis of the liver (alcoholic), ascites, hypertrophy and dilatation of the heart, mitral regurgi-

10. Bloor, W. R.: Jour. Biol. Chem., 1916, 25, 477.

11. In considering the figures for total fatty acids the fact must be taken into account that the samples of blood were taken at the time of parasynthesis, which, in every case, was in the afternoon two to four hours after the midday meal. 
tation and general arteriosclerosis. Omentopexy had been performed six years previously. The operation afforded some relief for about a year, but for the previous five years the patient had had to be tapped at gradually decreasing intervals. The results obtained on this patient are given in Table 2 .

The experimental diets used have been one containing the maximum amount of protein the patient could be induced to take, one containing the smallest amount of protein on which we could keep him reasonably contented, and one in which an attempt was made definitely to increase the cholesterol intake. For purposes of comparison the results obtained on a number of samples of fluid which were collected while the patient was on ordinary house diet have been included.

As will be seen from Table 2 the response to changes in food intake was prompt. During the two periods of high protein and high purin feeding the uric acid, nonprotein nitrogen and urea of the blood showed values much greater than those observed during the succeeding days of low protein intake. The period of high cholesterol intake was also marked by a considerable increase in the amount of this body present in the fluid collected during this time. Practically no changes were observed in the content of the total protein of the fluid as a result of changes in protein intake, a finding in accord with the observations of Müller, ${ }^{12}$ who found, in a patient with ascites due to a portal thrombosis, that an extremely high protein intake must be brought about before an increase in the amount of total protein in the ascitic fluid could be conclusively demonstrated.

\section{SUMMARY}

Results obtained by the quantitative examination of various types of edema fluids for their nonprotein constituents are presented. As a result of these analyses the following conclusions have been made:

1. That many of the nonprotein constituents of the fluids which belong to the class of crystalloids, among which may be mentioned urea, uric acid, and creatinin, occur in the same concentration in exudates and transudates as in the blood. The sugar content of ascitic fluids is somewhat higher than that of the blood, a finding not made in the case of the examples of pleuritic fluid analyzed.

In transudates, total creatin occurs only in small amounts. In fluids of the more purely exudate type it is present in considerably higher concentrations, frequently approaching closely the concentration found in whole blood.

12. Müller: Deutsch. Arch. f. klin. Med., 1903. 76, 563. 
2. Fat and cholesterol occur in transudates in relatively small amounts. In fluids obtained from acute cases the content of fat and cholesterol rises and the former may at times approximate the concen-trations found in blood.

3. In a patient with ascites from whom fluid was withdrawn every six to eight days, it was shown that the concentration of urea, uric acid and cholesterol in the fluid could be easily influenced by changes in diet. 